\title{
A STUDY OF THE EARTHQUAKE RESISTANCE
}

\section{OF DOMESTIC BREAK PRESSURE TANKS}

\author{
F.N. Blackwell*
}

\section{SUMMARY}

The paper reports on a series of dynamic tests on possible restraint systems for domestic break pressure tanks and recommends the use of wire guys if bracket supports cannot be rigidly attached to the tank walls.

\subsection{INTRODUCTION}

As normal mains pressure may burst the standard domestic hot water cylinder, it has been standard practice to install a break pressure tank in the roof space. The break pressure tanks are normally unrestrained against lateral movement, except by the inlet and outlet pipes, and they sit in an overflow tray on a timber platform supported by the ceiling joists. This means that the tanks most likely fail during an earthquake, not only losing a potentially useful source of emergency drinking water but also causing unnecessary damage. Provision of a simple inexpensive restraining system could overcome these problems.

A test was arranged to check suggested designs for the restraint of supply tanks to resist lateral earthquake forces. The test was sponsored by the N.Z. National Society for Earthquake Engineering.

The methods of restraint tested were chosen to be simple and inexpensive, to provide reasonable resistance to earthquake forces and to be simple enough for installation by the home handyman in the case of existing tanks.

\subsection{TEST FACILITIES}

Testing for earthquake resistance has difficulties as the forces, frequencies and duration of any one earthquake are unique. Also in choosing a design earthquake for testing, an upper limit in strength should be set to that level which can be sustained by the house itself. A further limitation is the availability of a test rig.

The N.Z. Pottery and Ceramics Research Association (Inc.) (PACRA) in Wellington has a rig suitable for the test but it can only produce sinusoidal oscillations in a horizontal direction. The maximum acceleration is limited to about $1.5 \mathrm{~g}$ and this is further limited at frequencies less than $3 \mathrm{~Hz}$ because of the travel required. $0.2 \mathrm{~g}$ is the maximum acceleration obtainable below $1.5 \mathrm{~Hz}$. Tests were planned to include these limitations.

\subsection{TEST PROCEDURE}

Two standard tanks were mounted

* Brickell, Moss, Rankine \& Hill, Consulting Engineers, Wellington. individually on a mock-up of ceiling joists and fixed to the PACRA shaking frame. The outlet and inlet pipes were aligned with the direction of movement. The frame was actuated hydraulically by a MAND actuator. Motion was horizontal and unidirectional. The tanks selected were as follows :

- A one piece moulded polythene 135 litre tank with loose fitting lid and separate polythene overflow tray. The height was $470 \mathrm{~mm}$, bottom diameter $572 \mathrm{~mm}$, top diameter $670 \mathrm{~mm}$ and thickness $2.5 \mathrm{~mm}$.

- A copper 135 litre tank fabricated by brazing the components together. The lid was a tight push fit with three holes for screws. The height was $610 \mathrm{~mm}$, diameter $560 \mathrm{~mm}$ and thickness $0.45 \mathrm{~mm}$.

In all tests the tanks rested directly on the polythene tray. The movements at the base and at the top of the tanks were monitored using strain gauge leaf deflectometers. However, due to the relatively large tank movements it was difficult to get accurate deflection readings and in several instances the tank movement exceeded the range of the deflectometers. Deflections over $12 \mathrm{~mm}$ tended to be unreliable. A portion of these larger deflections will be due to relative movement between the base of the tank and the timber frame.

During the test, the following aspects were carefully checked:

(a) Loss of water through the top of the tank. (The tank was refilled after each test.)

(b) Breaking, shearing or tearing of any part of the fixings.

(c) Serious tank deformation.

(d) Water leakage from tank due to cracking.

(e) Failure of pipe connections, pipe bends or pipe body.

The first test was conducted to determine the natural frequencies of the tanks. The amplitude was kept small at $2 \mathrm{~mm}$ and the frequency increased from $1 \mathrm{~Hz}$ to $12 \mathrm{~Hz}$ in about $2 \mathrm{~Hz}$ steps. As the tank platform slowed down after each test, resonance conditions were indicated by the platform displacement as plotted by a pen recorder. The runs lasted about 100 cycles.

The tanks were tested initially without any fastening to the platform, apart from the inlet and outlet pipes. The copper tank 
was tested both with and without wire supports as shown on the attached detail Fig. 1, but the plastic tank was tested unrestrained by wires. Subsequently various forms of base clamping were tried to investigate the effect of this form of fixing.

Following the resonance test the tanks were tested to the limit of the forces that could be provided by the test rig, to determine the method of failure and the best supporting system. applies :

The following theoretical relationship

Amplitude $(\mathrm{mm})=\frac{248.5}{(\text { frequency }-\mathrm{Hz})^{2}} \times \begin{gathered}\text { accelera } \\ \text { tion }\end{gathered}$

where $248.5=\frac{9.81 \times 1000}{4 \times \pi 2}$

Table 1 gives details of the test runs. Note that in an earthquake, serious accelerations in domestic dwellings tend to be in the range of 2 to $6 \mathrm{~Hz}$. They would be a little lower in taller buildings.

\subsection{Test 1: Unrestrained Plastic Tank}

The polythene tank was mounted on the test platform, unrestrained except for the inlet and outlet pipes. The tank was shaken at a range of frequencies to determine the natural frequency.

Water started to spill over the top of the tank at $4.0 \mathrm{~Hz}$. The bracket holding the bottom pipe worked loose and the tank moved on the platform. At the higher frequencies water loss and displacement of the tank continued. Test results are given in Table 2 .

\section{2 Test 2: Unrestrained Copper Tank}

The copper tank was mounted on the test platform unrestrained except for the inlet and outlet pipes. The tank was shaken at a range of frequencies to determine the natural frequency.

Water spillage over the top of the tank started at $5.0 \mathrm{~Hz}$ and continued at the higher frequencies. Test results are given in Table 3 .

\subsection{Test 3: Copper Tank Restrained by Wires}

The copper tank was mounted on the test platform and was restrained by the piping and by four 8 gauge galvanised steel wire guys. See detail Fig. 1 . The guys were separated from the copper tanks by PVC tape. The tank was shaken over a range of frequencies and the behaviour of the wiring system observed.

Significant water loss occured at $1.0 \mathrm{~Hz}$ (approx. 7 litres). The amount of water loss decreased as the shaking frequency increased.

The tank buckled at the base seam while being tested at $3.0 \mathrm{~Hz}$. Rotation of the tank within the wire guys was observed at 7.0 Hz. Test results are given in Table 4 .

The polythene tank was not tested in the restrained condition as it was concluded that its performance would be similar to the copper tank.

\subsection{Test 4: Copper Tank with Bottom Clanped (First Test)}

The copper tank was mounted on the test platform and restrained by four mild steel clips nailed to the platform and clamped down on the lower lip of the tank. A drawing of this fixing detail is given on Fig. 3 attached. The behaviour of the tank and fixings was observed at a range of frequencies.

At $1.0 \mathrm{~Hz}$ the lid lifted and approx. 9 litres of water was lost. At $2.0 \mathrm{~Hz}$ the tank lid came off and two of the retaining brackets slipped off the bottom lip. All brackets slipped off the lip at $3 \mathrm{~Hz}$ and one bracket was prized off the decking. slight denting to the tank at the bracket fixing point was observed at this stage.

All brackets were refixed to the deck using screws. (Previously the brackets had been fixed using galvanised clouts.) The tank lid was also fixed in place with screws. The test was then continued.

At $4.0 \mathrm{~Hz}$ all the brackets slipped off the lip and further damage to the tank at the bracket points was observed. Rotation of the tank was also observed. Test results are given in Table 5 .

\subsection{Tesi 5: Copper Tank Bottom Clamped (Second Test}

The tank was mounted as in Test 4 but was restrained by six mild steel clips.

The tank behaved satisfactorily except for minor water loss and rotation up to $3.0 \mathrm{~Hz}$. At $4.0 \mathrm{~Hz}$ four fixings slipped off the lip and punctured the tank. Test results are given in Table 6 .

\subsection{Test 6: Copper Tank - Unrestrained}

After the above tests were completed the tank was refilled and left unrestrained but the pipes were fixed rigidly and the tank tested to destruction. Failure occurred at the lower pipe/tank junction with the copper tank fracturing around the pipe entry (Table 7).

\subsection{OBSERVATIONS}

1. The copper tank full of water had a natural frequency at $15 \mathrm{~Hz}$ when free and $20 \mathrm{~Hz}$ when wired. The polythene tank had a natural frequency of $13.3 \mathrm{~Hz}$. The lowest natural frequency of the water in the tank was $1.35 \mathrm{~Hz}$. All these frequencies are within the earthquake range. The lowest water resonant frequency occurs only when the tank is rigidly attached to the platform. Without a lid, water loss is significant but ceases with frequencies about $7 \mathrm{~Hz}$. With the unrestrained tank, movement of the tank reduces the water loss at lower frequencies. Maximum loss occurs between approximately 4 and $10 \mathrm{~Hz}$. The lid must be securely fixed to prevent water loss.

Fitting baffles will reduce the water loss but these are impractical as they would be expensive and would interfere with 

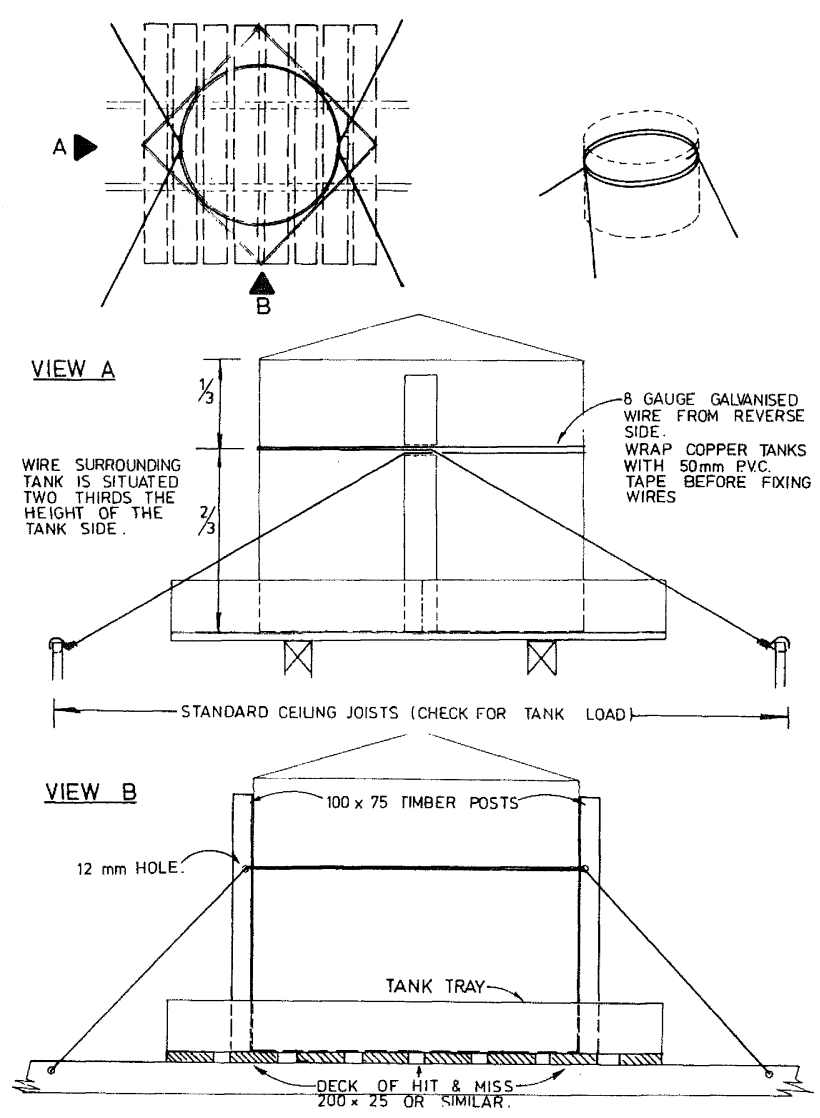

FIGURE 1: WIRE SUPPORT FOR TANK
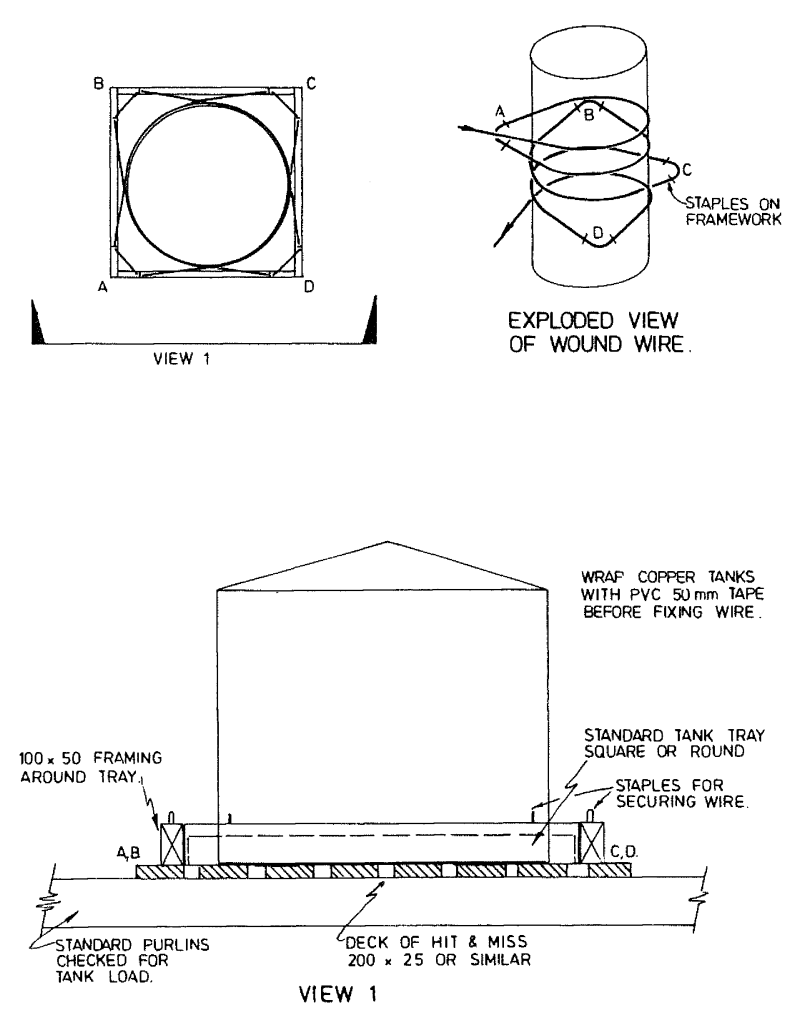

FIGURE 2: ALTERNATIVE WIRE SUPPORTFORTANK

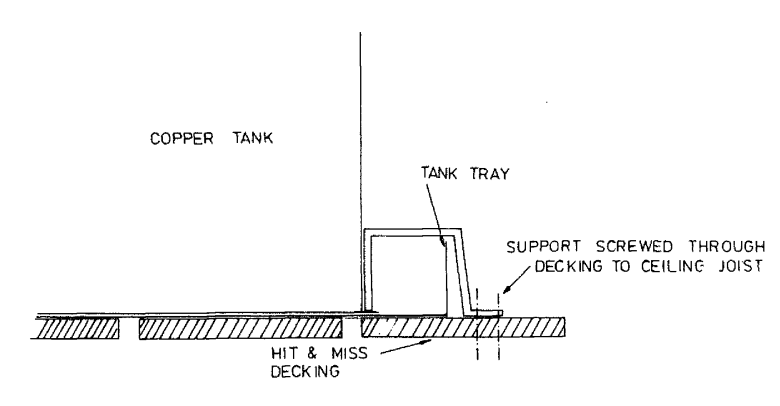

SECTION SHOWING SUPPORT BRACKET 
the ball valve.

2. Serious tank damage started to occur at 3 to $4 \mathrm{~Hz}$. This is probably caused by the acceleration reaching its maximum level in this frequency range - a limitation of the testing machine.

3. Brackets as shown in Fig. 3 are easier to install but increase the deflection of the tanks and will lead to failure if they are not adequately fastened (i.e. screwed solidly to timber). Probably satisfactory in a typical earthquake to accelerations of $\mathrm{l.0g}$ in a ceiling.

4. Wire guys are more difficult to install but the tank would probably be satisfactory in a typical earthquake to accelerations of $2.0 \mathrm{~g}$ in a ceiling. Some movement in the tank is beneficial as this reduces tank deflection. There was also some rotation, so pipe flexibility is essential.

5. The standard unfastened tank will probably fail at a ceiling acceleration of $0.5 \mathrm{~g}$ by failure of the pipe connection. This would happen in a moderately severe earthquake.

6. Note that the tests were conducted with nearly pure sine wave motion which accentuates tank resonances. As stated previously, it was not possible to programme the shaking table for an actual earthquake but we estimate from the tests that the tank supported as shown in Fig. 1 would withstand an earthquake equal to $3.0 \mathrm{x} \mathrm{El}$ Centro if located on the ground and 1 to $1.5 \mathrm{x}$ El centro if placed in the ceiling space of a single storied timber framed house constructed in accordance with NZS 1900.

7. Significant rotation can occur even with unidirectional accelerations so an anchoring system should be designed to prevent this.

\subsection{RECOMMENDATIONS}

The following recommendations are made:

1. That the details based on wire guys be promulgated as the recommended method for seismic restraint of domestic break pressure tanks. Bracket supports would be adequate provided they can be rigidly attached to the tank walls.

2. As all pipework should remain intact, the hot water cylinder must also be fastened against earthquake forces and accordingly the recommendations in the BRANZ publication No. R23 are supported.

3. That tank suppliers be approached to include brackets with their tanks for anchoring. Note that as the tanks are relatively thin, supports that take the forces in tension will be much more successful than those acting in compression. An alternative simpler solution is shown in Fig. 2 but cannot be as effective as Fig. 1 because it will allow the tank to lift. This arrangement has not been tested.

\subsection{ACKNOWLEDGEMENTS}

The author would like to thank the Earthquake Society and Messrs. G. McKenzie,
W. Toomath, I. Skinner, P. Clark, P. Thorby and I. Smith for assistance in arranging and completing the tests.

\subsection{COMMENTS BY MR. I. SKINNER}

Test 1 (Para 3.1)

From the observed fundamental frequency of $1.35 \mathrm{~Hz}$ for water sloshing in the copper tank it is expected that the plastic tank would have a corresponding period of about $1.35 \times 560=1.13 \mathrm{~Hz}$.

$$
\frac{560}{670}
$$

Hence run 1 should have had fundamental sloshing but the acceleration is too low to cause spillage.

The spilling which occurred during runs 4 to 10 was associated with higher modes of sloshing with lower loads on the tank than arise from mode 1 sloshing.

During runs 8 to 10 the bottom sliding was a significant fraction of the platform displacement and would have given rise to coulomb damping of about $5 \%$.

The lowest tank natural frequency of 1.3. $3 \mathrm{~Hz}$ was not reached during Test 1 .

Test 2 (Para 3.2)

Behaviour was similar to the plastic tank during test 1 .

Significant coulomb damping occurred during runs 3 to 5 and cumulative base displacement occurred during run 5 .

Test 3 (Para 3.3)

With larger accelerations near the fundamental water-sloshing natural frequency, water was lost and there would have been an associated increase in lateral loads.

The rotation observed during run 7 would tend to be more severe under the multidirection accelerations of an actual earthquake. Notice that water-sloshing natural frequencies will increase with amplitude for all amplitudes which cause waves to strike the lid. This will reduce the likelihood of coincident water and building periods and associated severe sloshing - provided the lid is fixed in place.

Test 4 (Para 3.4)

The large top displacements during runs 5 and 6 are presumably largely due to base sliding. Such effects should be inhibited by the wiring method shown on Fig. 1 .

\section{Discussion}

It is difficult to estimate the "size" of earthquake (e.g. multiplier to be applied to El Centro $1940 \mathrm{~N}-\mathrm{S}$ accelerations) to correspond to the sinusoidal shaking tests.

When the tank is supported at a high level by bracing wires, as in Fig. 1 , and when the lid is securely fastened, then sinusoidal shaking at frequencies of 3 to 6 $\mathrm{Hz}$ would have only moderate resonant magnification of forces and movements. These forces and movements should be similar to 
those of the test platform.

When tested under these conditions an appropriate test duration would be 10 to 20 cycles.

The maximum acceleration at the ceiling of a somewhat flexible timber frame dwelling is expected (from unpublished work by Trevor Kelly, M.W.D.) to be 2 to 3 times the maximum ground acceleration. Hence an appropriate test to simulate the attack of the El Centro $1940 \mathrm{~N}-\mathrm{S}$ earthquake motions would be 15 cycles of sinusoidal motion with peak accelerations of $1.0 \mathrm{~g}$.

When the tank is held by wires or clamps near its base then there may be increased resonant magnification associated with tank wall deformation. In this case the resonant magnifications during earthquake motions may be substantially less than occurs during testing with sinusoidal motions. Hence the El Centro attack might be simulated with sinusoidal accelerations into peak values of about $0.7 \mathrm{~g}$.

Paper received 18 April, 1979.

\section{TABLE 1}

DETAILS OF TEST RUNS

\begin{tabular}{|c|c|c|c|c|c|c|c|c|c|c|}
\hline Acceleration: & 0.05 & 0.2 & 0.61 & 0.87 & 1.0 & 1.0 & 1.0 & 1.0 & 1.0 & $1.0 \times \mathrm{g} \mathrm{m} / \mathrm{sec}^{2}$ \\
\hline $\begin{array}{l}\text { Shaking } \\
\text { Frequency: }\end{array}$ & 0.5 & 1 & 2 & 3 & 4 & 5 & 7 & 9 & 10 & $\mathrm{~Hz}$ \\
\hline $\begin{array}{l}\text { Shaking } \\
\text { Amplitude: }\end{array}$ & 50 & 50 & 38 & 24 & 15.5 & 10 & 5.1 & 3.1 & 2.38 & 2.1 \\
\hline
\end{tabular}

TABLE 2

RESULTS FOR UNRESTRAINED PLASTIC TANK

\begin{tabular}{|c|c|c|c|c|c|}
\hline Run & Frequency & Amplitude & Acceleration & $\begin{array}{c}\text { Top } \\
\text { Displace- } \\
\text { ment } \\
(\mathrm{mm})\end{array}$ & $\begin{array}{c}\text { Bottom } \\
\text { Displace- } \\
\text { ment } \\
(\mathrm{mm})\end{array}$ \\
\hline 1 & $(\mathrm{~Hz})$ & $(\mathrm{mm})$ & $(\mathrm{g})$ & .002 & \\
2 & 1.0 & 1.8 & .007 & .08 & .01 \\
3 & 1.5 & 2.0 & .018 & .005 & .08 \\
4 & 2.0 & 1.9 & .031 & .11 & .05 \\
5 & 4.0 & 2.5 & .22 & .14 & .06 \\
6 & 5.0 & 2.2 & .33 & .14 & .06 \\
7 & 6.0 & 2.3 & .56 & .16 & .35 \\
8 & 1.0 & 2.2 & 1.11 & .35 & .25 \\
9 & 11.0 & 2.0 & 1.29 & .27 & .27 \\
10 & 13 & 1.9 & & &
\end{tabular}

TABLE 3

RESULTS FOR UNRESTRAINED COPPER TANK

\begin{tabular}{|c|c|c|c|c|c|}
\hline Run & $\begin{array}{l}\text { Frequency } \\
(\mathrm{Hz})\end{array}$ & $\begin{array}{l}\text { Amplitude } \\
\text { (mm) }\end{array}$ & $\begin{array}{c}\text { Acceleration } \\
\text { (g) }\end{array}$ & $\begin{array}{c}\text { Top } \\
\text { Displace- } \\
\text { ment } \\
\text { (mm) }\end{array}$ & $\begin{array}{l}\text { Bottom } \\
\text { Displace- } \\
\text { ment } \\
(\mathrm{mm})\end{array}$ \\
\hline $\begin{array}{l}1 \\
2 \\
3 \\
4 \\
5\end{array}$ & $\begin{array}{l}1.0 \\
3.0 \\
5.0 \\
7.0 \\
9.0\end{array}$ & $\begin{array}{l}1.8 \\
2.3 \\
1.85 \\
1.9 \\
1.9\end{array}$ & $\begin{array}{l}.007 \\
.09 \\
.19 \\
.38 \\
.62\end{array}$ & $\begin{array}{l}.5 \\
.13 \\
.13 \\
.8\end{array}$ & $\begin{array}{l}.13 \\
.25 \\
9.3\end{array}$ \\
\hline
\end{tabular}


TABLE 4

RESULTS FOR COPPER TANK RESTRAINED BY WIRES

\begin{tabular}{|c|c|c|c|c|c|}
\hline Run & $\begin{array}{c}\text { Frequency } \\
(\mathrm{Hz})\end{array}$ & $\begin{array}{l}\text { Amplitude } \\
\text { (mm) }\end{array}$ & $\begin{array}{c}\text { Acceleration } \\
\text { (g) }\end{array}$ & $\begin{array}{l}\text { Top } \\
\text { Displace- } \\
\text { ment } \\
(\mathrm{mm})\end{array}$ & $\begin{array}{l}\text { Bottom } \\
\text { Displace- } \\
\text { ment } \\
(\mathrm{mm})\end{array}$ \\
\hline $\begin{array}{c}1 \\
2 \\
3 \\
4 \\
5 \\
6 \\
7 \\
8 \\
9 \\
10\end{array}$ & $\begin{array}{l}0.5 \\
1.0 \\
2.0 \\
3.0 \\
4.0 \\
5.0 \\
7.0 \\
9.0 \\
11.0 \\
1.35\end{array}$ & $\begin{array}{c}100 \\
100 \\
74 \\
48 \\
32 \\
24 \\
16 \\
8.4 \\
5.8 \\
\text { Nat. Ereq. }\end{array}$ & $\begin{array}{c}.1 \\
1.4 \\
1.19 \\
1.74 \\
2.0 \\
2.4 \\
3.16 \\
2.74 \\
3.08 \\
\text { - no meas } \\
\end{array}$ & $\begin{array}{l}.131 \\
1.5 \\
2.8\end{array}$ & $\begin{array}{r}.5 \\
4.8\end{array}$ \\
\hline
\end{tabular}

\section{TABBL 5}

RESULTS OF FIRST TEST FOR BOTTOM CLAMPED COPPER TANK

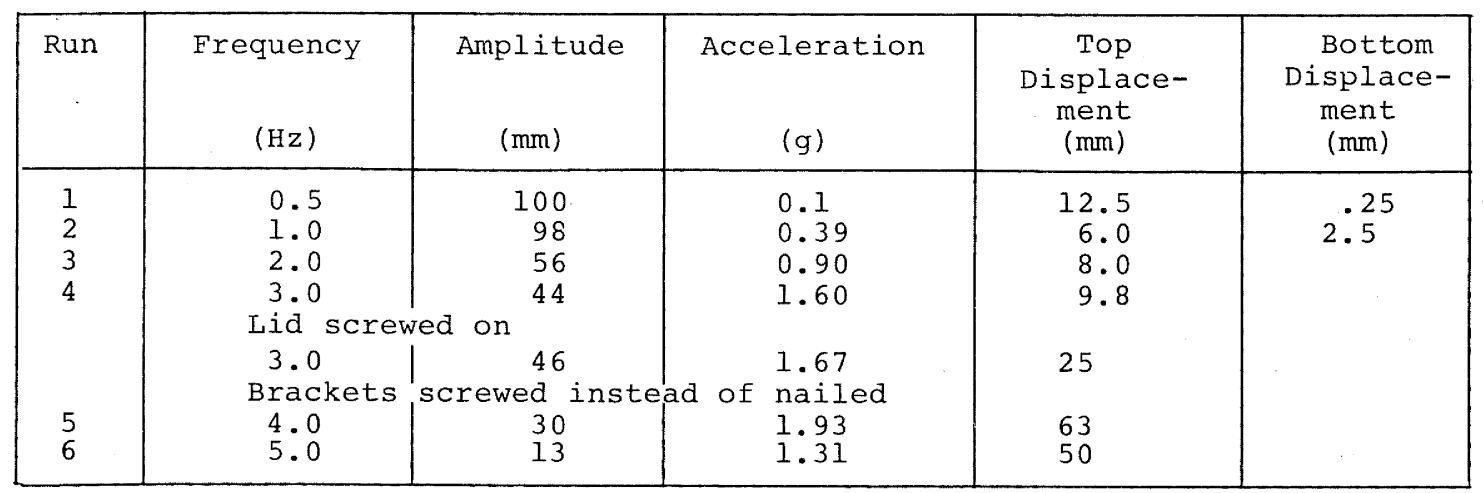

TABLE 6

RESULTS OF SECOND TEST ON BOTTOM CLAMPED COPPER TANK

\begin{tabular}{|c|c|c|c|c|c|}
\hline Run & Frequency & Amplitude & Acceleration & $\begin{array}{c}\text { Top } \\
\text { Displace- } \\
\text { ment } \\
(\mathrm{mm})\end{array}$ & $\begin{array}{c}\text { Bottom } \\
\text { Displace- } \\
\text { ment } \\
(\mathrm{mm})\end{array}$ \\
\hline 1 & $(\mathrm{~Hz})$ & $(\mathrm{mm})$ & $(\mathrm{g})$ & 10 & \\
2 & 1.0 & 100 & .40 & 15 & \\
3 & 3.0 & 46 & 1.22 & 33 & \\
4 & 4.0 & 28 & 1.67 & 65 & \\
\hline
\end{tabular}

TABLE 7

RESULTS FOR UNRESTRAINED COPPER TANK

\begin{tabular}{|l|c|c|c|c|c|}
\hline Run & Frequency & Amplitude & Acceleration & $\begin{array}{c}\text { Top } \\
\text { Displace- } \\
\text { ment } \\
(\mathrm{mm})\end{array}$ & $\begin{array}{c}\text { Bottom } \\
\text { Displace- } \\
\text { ment } \\
(\mathrm{mm})\end{array}$ \\
\hline 1 & $(\mathrm{~Hz})$ & $(\mathrm{mm})$ & $(\mathrm{g})$ & & \\
\hline 2 & $\begin{array}{l}4.0 \\
1.35\end{array}$ & 28 & 1.80 & 0.73 & \\
\hline
\end{tabular}

